\title{
Stakeholder-based Brand Equity Affecting Marketing Performance
}

\author{
Rungtiwa Wongprasha*, Vichit U-on \\ Graduate College of Management, Sripatum University, Thailand
}

Copyright $\odot 2016$ by authors, all rights reserved. Authors agree that this article remains permanently open access under the terms of the Creative Commons Attribution License 4.0 International License

\begin{abstract}
The establishment of the ASEAN Economic Community (AEC) in 2015 is a major milestone in the regional economic integration agenda in ASEAN, offering opportunities in the form of a huge market of US\$2.6 trillion and over 622 million people. A vital role of private universities is expected to grow increasingly. Private universities must self-improve for the establishment of the AEC, to keep up with up to date and changing environment. Nowadays, a pattern of Thai private universities has been gradually changed. All stakeholders involved with the private universities may rely on the governmental sector. They should determine policy that supports enhancement towards international educational baseline. Therefore, standardized system of Thai education must be established and compliance. Currently, Private universities compete with each other to succeed drawing a number of incoming students. It is obvious that private universities then rely on stakeholder brand equity in order to differentiate among private universities that lead to brand creation. Building awareness of private universities and association with any stakeholders is crucial for public and private educations as a whole . The objectives of this study were to: 1) identify influencing factors affecting stakeholder-based brand equity for Thai private universities, and 2) review stakeholder-based brand equity affecting marketing performance. Research methodology includes with population and sampling determination which are 10 private universities, along with students, alumni, parents, and graduates of 800 subjects. This research study used multi stage sampling for collecting data from October to December 2015. The response rate was $100 \%$ of 800 questionnaires. For the data analysis, it appeared that the study used structural equation modeling in which the analysis was found that customer relationship management, marketing mix 7'ps, perceived service quality positively affecting stakeholder-based brand equity. It was also reviewed that stakeholder-based brand equity positively affecting marketing performance. Besides that, marketing performance was slightly affected by customer relationship
\end{abstract}

management, marketing mix 7'ps, and perceived service quality that were relevant to determined hypotheses.

Keywords Customer Relationship Management, Marketing Mix, Perceived Service Quality, Stakeholder-based Brand Equity, Market Performance

\section{Introduction}

The establishment of the ASEAN Economic Community (AEC) in 2015 is a major milestone in the regional economic integration agenda in ASEAN, offering opportunities in the form of a huge market of US\$2.6 trillion and over 622 million people. A vital role of Thai private system is expected to grow increasingly. Nowadays, a pattern of Thai private system has been gradually changed. All stakeholders who are involved with this Thai private system may rely on governmental sector to determine a number of policies supporting enhancement towards international baseline. Therefore, standardized system of such Thai education must be established and compliance. Private universities at the present time have competed to succeed drawing a number of incoming students. It is obvious that private universities then rely on stakeholder brand equity in order to differentiate among private universities that lead to brand creation. Building awareness of private universities and association with any stakeholders is crucial for public and private educations as a whole. Most of private universities extremely compete for academic, curriculum, lecturer, students' screening, tuition fee, and brand image promotion. These factors have been found to develop competitiveness succeeding other competitors. To promote universities' brand image, private universities must strongly aware and fairly associate with other stakeholders that leads to customer satisfaction and loyalty. Such that case, it would increase marketing performance of private universities. Aker; (1991) Keller; (1993, 2003) said that the Customer Based Brand Equity caused by creating a strong brand in the minds 
of customers. Luming Wangz (2011) and Wei et al. (2010) has said that the brand represents the overall features of products and services in the heart of the customer. The brand's products and services were the elements and create value for the customer's satisfaction and fulfillment. McCarthy (1971), Booms and Bitner (1981), (Kotler, 2011), and Jonathan (2008) said that the marketing strategy services as a strategy to make a difference and create an advantage in the race.

Furthermore, the concept of customer relationship management may involve a business strategy that leads to the creation of value to business and customers. It may be done by building relationships and maintaining long-term customer relationships. Competitive advantage with sustainability of the business services was conducted by Day (1994), Day, (2003), \& Yim et al. (2004); Sin et al., (2005); and Van den Bulte (2002) corresponds to Pasves. et al. (2013). It was found that the clients get the service quality of the experience of the service caused by expectations. Effects of the performance towards brand awareness for sustainable institution were conducted by Parasuraman and Berry et al. (1985), Zabed et al. (2009), Koushiki et al. (2013), Lewlyn. Et al. (2013), and Ahmadrazaet al. (2011). Mohmmadal et al. (2013) found that satisfaction of customer needs, and expectations and attitudes towards brand value in the customer's perspective. Oliver $(1980 ; 2003)$ also conducted a study of satisfaction and expectations towards the recognition of brand performance and satisfaction with the perceived quality of the goods or services. Meanwhile, Mohsin (2012) found that the quality of customer services may contribute to customer satisfaction. Thereby, the objectives of this study were to: 1) identify influencing factors affecting stakeholder-based brand equity for Thai private universities, and 2) review stakeholder-based brand equity affecting marketing performance for Thai private universities.

\section{Literature Review}

\subsection{Customer Based Brand Equity}

Customer-based brand equity (CBBE) is a way of assessing the value of a brand in customers' minds. Branding can increase profitability in large and small-scale businesses by filling in gaps in customers' knowledge and by offering assurances. The CBBE model centers that value in the minds of customers. It compels businesses to define their brands according to a defined hierarchy of qualitative, or common-sense, customer impressions. These impressions are often laid out in pyramid-shaped levels; they consist of salience, performance, imagery, meaning, judgments, feelings, and resonance. Equity can be considered the sum total of values associated with a brand. These might include awareness, loyalty, and recognition. The greater the equity, the more likely customers will trust and choose the company's product or service. Additionally, equity capitalizes on normal psychological tendencies, such as the sometimes longer memory about negative experiences or the cognitive laziness that creates loyalty through a customer's unwillingness to choose unfamiliar products over familiar brand products. Salience represents the bottom of the customer-based brand equity pyramid. This refers to what customers associate with a particular brand. It describes the very basics of what customers think about when they hear the name and how frequently they might think of it. Essentially, brand salience represents the depth and breadth of brand awareness.

\subsection{Customer Relationship Management}

Customer relationship management (CRM) is an approach to managing a company's interaction with current and future customers. The CRM approach tries to analyze data about customers' history with a company, in order to better improve business relationships with customers, specifically focusing on retaining customers, in order to drive sales growth. One important aspect of the CRM approach is the systems of CRM that compile information from a range of different channels, including a company's website, telephone, email, live chat, marketing materials, social media, and more. Through the CRM approach and the systems used to facilitate CRM, businesses learn more about their target audiences and how to best cater to their needs. However, the adoption of the CRM approach may also occasionally lead to favoritism within an audience of consumers, leading to dissatisfaction among customers and defeating the purpose of CRM.

\subsection{Marketing Mix 7'ps}

The term "marketing-mix" was first coined by Neil Borden, the president of the American Marketing Association in 1953. It is still used today to make important decisions that lead to the execution of a marketing plan. The various approaches that are used have evolved over time, especially with the increased use of technology. The marketing mix is a business tool used in marketing and by marketers. The marketing mix is often crucial when determining a product or brand's offer, and is often associated with the four Ps: price, product, promotion, and place. In service marketing, however, the four Ps are expanded to the seven Ps or Seven Ps to address the different nature of services. In the 1990s, the concept of four C's was introduced as a more customer-driven replacement of four P's. There are two theories based on four Cs: Lauterborn's four Cs (consumer, cost, communication, convenience), and Shimizu's four Cs (commodity, cost, communication, channel). In 2012, a new four P's theory was proposed with people, processes, programs, and performance. 


\subsection{Service Quality}

A business with high service quality will meet customer needs whilst remaining economically competitive. Improved service quality may increase economic competitiveness. This aim may be achieved by understanding and improving operational processes; identifying problems quickly and systematically; establishing valid and reliable service performance measures and measuring customer satisfaction and other performance outcomes. Measuring service quality may involve both subjective and objective processes. In both cases, it is often some aspect of customer satisfaction which is being assessed. However, customer satisfaction is an indirect measure of service quality. The relationship between service quality and customer satisfaction has received considerable attention in academic literature. The results of most research studies have indicated that the service quality and customer satisfaction are indeed independent but are closely related that and a rise in one is likely to result in an increase in another construct.

\subsection{Market Performance}

Marketing performance measurement and management (MPM) is the systematic management of marketing resources and processes to achieve measurable gain in return on investment and efficiency, while maintaining quality in customer experience. Marketing performance management is a central facet of the marketing operations function within marketing departments. Marketing performance management relies on a set of measurable performance standards, a pointed focus on outcomes, and clear lines of accountability (i.e. roles and consequences). Marketing performance management is based on six success factors: 1) alignment, 2) accountability, 3) analytics, 4) automation, 5) alliances, and 6) assessment

\section{Conceptual Framework}

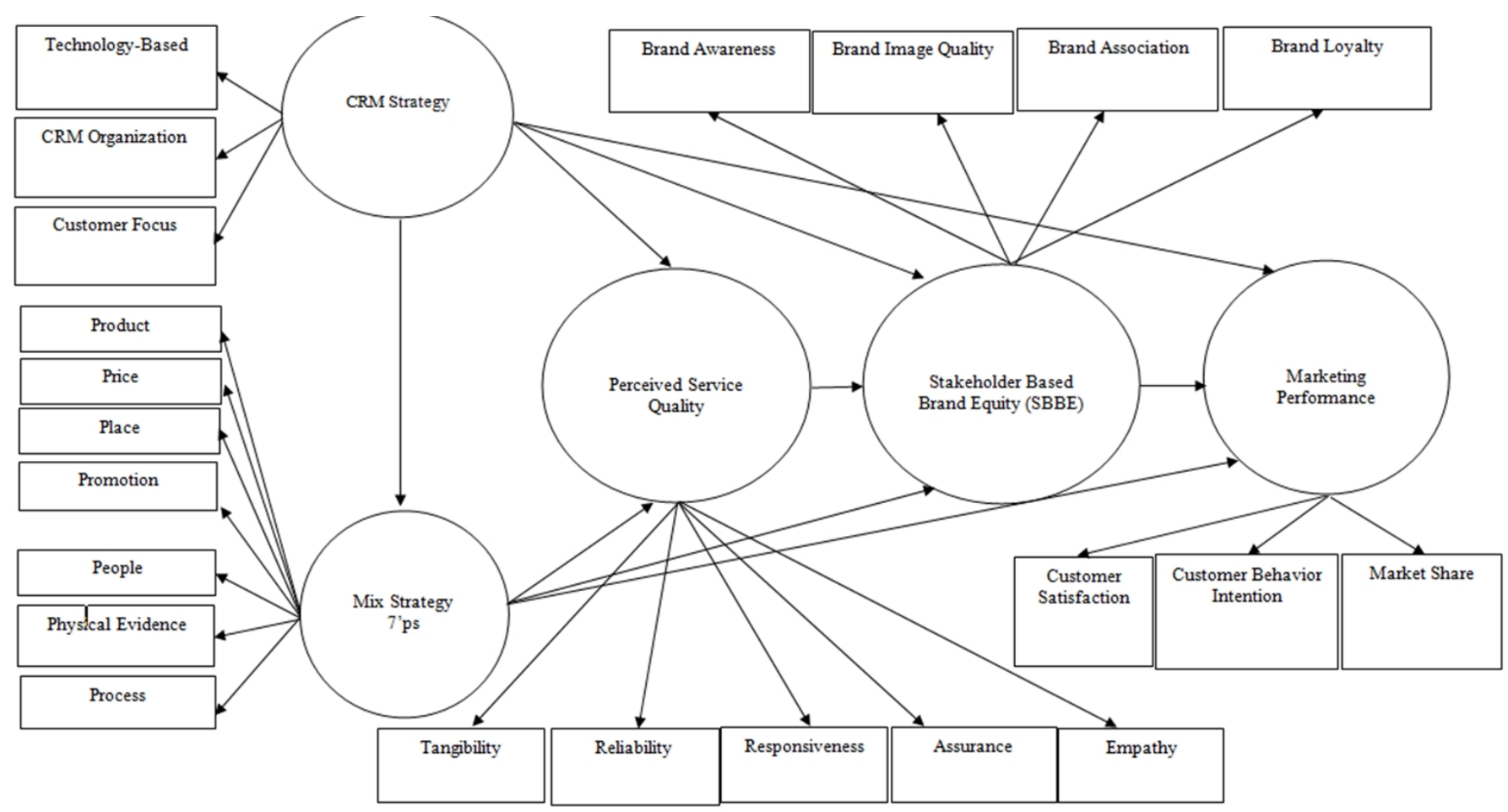

Figure 1. Conceptual Framework of the Research 


\section{Research Methodology}

Research on stakeholder-based brand equity was mixed methods that include qualitative research and quantitative research. Basically, this research study collected data from management involving stakeholder-based brand equity in Thai private universities. That includes with president, vice president, or dean was asked for in-depth interview that was found to be qualitative research. By collecting data by using a questionnaire, it contains questions involving with rational behind of stakeholder-based brand equity in Thai private universities. The questionnaire was developed, based on literature review, literature survey and it fulfills research objectives. Secondly, the quantitative research includes survey research interviewing private companies, parent, students, and graduate. Influencing factors affecting stakeholder-based brand equity were used to develop a strategy of customer relationship management, marketing mix, and perceived service quality. The stakeholder-based brand equity also affected marketing performance in which the brand equity comprising with brand image, brand awareness, brand association, brand loyalty. Marketing performance was measured with stakeholder's satisfaction; stakeholder's buying behavior, and marketing mix.

\subsection{Population}

Population was selected by the stakeholders from Thai private universities, including student, graduate, parent, and private company of 10 universities. In order to getting a sampling size with high confidence level, this research study selected 80 people from 10 universities. Therefore, the sampling size was totaled of 800 . Using the yamane's formula (1973), the required sampling size was then 800 samplings.

\subsection{Sampling Size}

The sampling size contains with multi-stage sampling separating into four small groups of population or two steps. A first step determines population according to geographical segmentation. One was for Bangkok and its perimeter, comprising of 10 private universities. Secondly, a sample was chosen from private universities using systematic sampling with probability. The sampling was made with 5 ranges from population house registration.

\subsection{Apparatus}

The research study presented here was the mixed method of qualitative research and quantitative research. A questionnaire was made for data collection, tested with validity and reliability.

\subsection{Data Analysis}

Descriptive statistics is the discipline of quantitatively describing the main features of a collection of information, or the quantitative description itself. Some measures that are commonly used to describe a data set are measures of central tendency and measures of variability or dispersion. Measures of central tendency include the mean, median and mode, while measures of variability include the standard deviation (or variance), the minimum and maximum values of the variables, kurtosis, and skewness using SPSS for Windows version 20.

Structural equation modeling refers to a diverse set of unrelated computer algorithms and statistical methods that fit networks of constructs to data. Structural equation modeling includes confirmatory factor analysis, path analysis, partial least squares path analysis, LISREL for Windows version 8.80 and latent growth modeling. In structural equation modeling, the fit indices establish whether, overall, the model is acceptable. If the model is acceptable, researchers then establish whether specific paths are significant. Acceptable fit indices do not imply the relationships are strong. Indeed, high fit indices are often easier to obtain when the relationships between variables are low rather than high--because the power to detect discrepancies from predictions are amplified. Many of the fit indices are derived from the chi-square value. Conceptually, the chi-square value, in this context, represents the difference between the observed covariance matrix and the predicted or model covariance matrix. The fit indices can be classified into several classes. These classes include:

- Discrepancy functions, such as the chi square test, relative chi square, and RMS

- Tests that compare the target model with the null model, such as the CFI, NFI, TFI, and IFI

- Information theory goodness of fit measures, such as the $\mathrm{AIC}, \mathrm{BCC}, \mathrm{BIC}$, and $\mathrm{CAIC}$

- Non-centrality fit measures, such as the NCP.

\section{Results Analysis}

The analysis was conducted with descriptive statistics identifying stakeholder-based brand equity for Thai private universities that contain with four groups shown as follows: 


\begin{tabular}{|c|c|c|c|c|c|c|c|c|c|c|}
\hline \multirow{2}{*}{$\begin{array}{c}\text { Factors Affecting Stakeholder-Based } \\
\text { Brand Equity }\end{array}$} & \multicolumn{2}{|c|}{ Students } & \multicolumn{2}{|c|}{ Graduates } & \multicolumn{2}{|c|}{ Parent } & \multicolumn{2}{|c|}{ Private Universities } & \multicolumn{2}{|c|}{ Total } \\
\hline & $\mathrm{x}$ & SD. & $\mathrm{x}$ & SD. & $\mathrm{x}$ & SD. & $\mathrm{x}$ & SD. & $\mathrm{x}$ & SD. \\
\hline Stakeholder-Based Brand Equity & 3.971 & 0.594 & 4.136 & 0.466 & 3.930 & 0.577 & 3.737 & 0.577 & 3.943 & 0.573 \\
\hline Customer Relationship Management & 3.935 & 0.600 & 3.930 & 0.527 & 3.947 & 0.597 & 3.745 & 0.565 & 3.889 & 0.578 \\
\hline Marketing Mix 7S & 3.942 & 0.574 & 4.010 & 0.464 & 3.965 & 0.566 & 3.783 & 0.502 & 3.925 & 0.534 \\
\hline Perceived Service Quality & 3.904 & 0.651 & 4.010 & 0.523 & 4.004 & 0.589 & 3.769 & 0.521 & 3.922 & 0.581 \\
\hline Marketing Performance & 3.921 & 0.689 & 4.058 & 0.623 & 3.948 & 0.683 & 3.718 & 0.686 & 3.911 & 0.681 \\
\hline
\end{tabular}

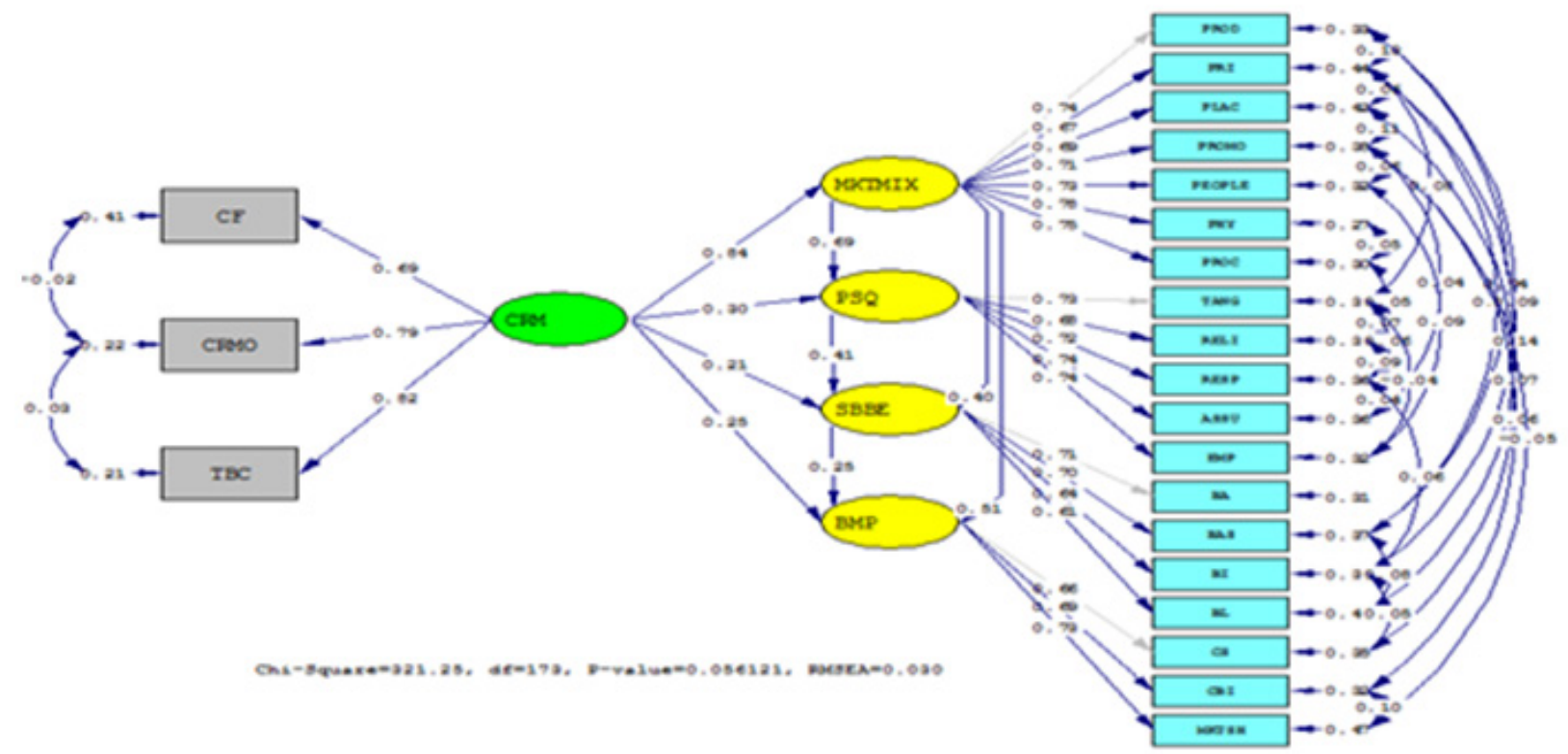

Figure 2. Results of Structural Equation Modeling With Acceptable Fit Indices

\subsection{Descriptive Statistics}

The descriptive statistics reviewed stakeholder-based brand equity for Thai private universities comprising four groups. Factors affecting the stakeholder-based brand equity had highest mean score of 3.943 and 0.573 standard deviation. For the marketing mix $7 \mathrm{~s}$, it was averaged that equals to 3.925 with standard deviation of 0.534 , perceived service quality had average score of 3.922 and 0.581 standard deviation. Furthermore, the average score of marketing mix was 3.911, and standard deviation of 0.681 while the lowest score of customer relationship management was 3.899, and standard deviation of 0.587 .

\subsection{Structural Equation Modeling}

The structure equation modeling reviewed stakeholder-based brand equity, analyzed by using maximum likelihood with LISREL 8.80 to compare the fit indexes. The acceptable fit indices were developed with empirical studies. Statistics evaluation may comprise of Chi-Square, $\chi^{2} / \mathrm{df}$, CFI, GFI, AGFI, RMSEA and SRMR. The model analysis was conducted with 6 acceptable fit indices such as $\chi^{2} / \mathrm{df}=1.86, \mathrm{CFI}=1.00, \mathrm{GFI}=0.96$, AGFI $=0.95$, RMSEA $=0.030$, and $\mathrm{SRMR}=0.019$. Therefore, the structural equation modeling illustrated acceptable fit indices shown in Figure 1.

1. $\chi^{2} / \mathrm{df}$ equals to 1.86 , a model is empirical studies fit due to $\chi^{2} / \mathrm{df}$ was less than 2.00 .

2. Comparative Fit Index: CFI equals to 1.000 , a model is comparative fit due to CFI was less than 0.90 .

3. Absolute Fit Index considering Goodness of Fit Index (GFI) equals to 0.96, and Adjusted Goodness of Fit Index (AGFI) that equals to 0.95, a model is empirical studies fit due to GFI and AGFI had a score between 0 and 1 , as well as GFI and AGFI was acceptable more than 0.90 .

4. Root Mean Square Error of Approximation: RMSEA) equals to 0.030 , a model is empirical studies fit due to RMSEA was less than 0.05 , or between 0.05 and 0.08 .

5. Standardized Root Mean Square Residual (SRMR ( equals to 0.019 , a model is empirical studies fit of less than 0.05 .

\subsection{Data Analysis According to Research Hypotheses}

The analysis was conducted based on determined research hypotheses with the following details:

Hypothesis 1: strategy of customer relationship management positively affecting marketing mix $7 \mathrm{~S}$.

Hypothesis 2: strategy of customer relationship 
management positively affecting perceived service quality.

Hypothesis 3: strategy of marketing mix $7 \mathrm{~S}$ positively affecting perceived service quality.

Hypothesis 4: strategy of perceived service quality positively affecting stakeholder-based brand equity.

Hypothesis 5: strategy of brand equity positively affecting marketing performance.

Hypothesis 6: strategy of marketing mix 7S positively affecting stakeholder-based brand equity.

Hypothesis 7: strategy of customer relationship management positively affecting stakeholder-based brand equity.

Hypothesis 8: strategy of marketing mix 7S positively affecting marketing performance.

Hypothesis 9: strategy of customer relationship management positively affecting marketing performance.

\section{Conclusions and Recommendation}

\subsection{Conclusions}

The research study presented here investigated the stakeholder-based brand equity for Thai private universities that includes two objectives: identifying influencing factors affecting stakeholder-based brand equity for Thai private universities, and reviewing stakeholder-based brand equity affecting marketing performance. The results indicated were relevant to the research conducted by Aker 1996 and kellel (2003). The research investigated into three different aspects: questionnaire; average and standard deviation on stakeholder-based brand equity, customer relationship management, marketing mix 7S, perceived service quality, and marketing performance; and acceptable fit indices to empirical studies.

\section{General Data from Questionnaire}

Normally, the subjects were female (67 percent), and age ranged from 19 to 20 years old (45 percent). Most of the subjects studied in Business Administration (100 percent), and were in a second year (38 percent). The graduate subjects were mostly female ( 68.5 percent), had and age ranged between 26 to 30 years old ( 37.5 percent). Most of the graduates completed their degree since 1 to 3 years (39.5 percent), and worked for marketing (16.5 percent). Parents mostly had aged from 41 to 45 years old (24 percent) with a Bachelor's degree graduate (43.5 percent). It was also found that most of the graduates were female (51.0 percent), and had age ranged from 41 to 45 years old ( 19.5 percent). Most of them graduated from a Master's degree (49.5 percent), and it were found that senior management appointed for managing director (50.0 percent) with secondly assistant to managing director (11.9 percent).

Fit Indices for Stakeholder-Based Brand Equity for Thai Private Universities
The analyzed model found that the fit indices did not fit to empirical studies or standard. This study modified the model by adjusting parameters that allows relative errors. The results indicated that acceptable fit indices identified by 6 indices $\left(\chi^{2} / \mathrm{df}=1, \mathrm{CFI}=1.00, \mathrm{GFI}=0.96, \mathrm{AGFI}=0.951\right.$, RMSEA $=0.030$ and SRMR $=0.019)$. Therefore, the structure equation modeling was then conducted in order to fit with the empirical studies.

\subsection{Discussion}

The research presented here identified the stakeholder-based brand equity for Thai private universities tested by research hypotheses. It was summarized that: The stakeholder-based brand equity insignificantly affected marketing performance at a significance level of 0.05 . Considering the results, it was complied with determined research hypotheses in which the stakeholder-based brand equity affecting brand awareness. The private universities should improve brand awareness by relating to universities' logo that reflects to students' quality. Any curriculums that were quickly recalled may identify the quality of universities. This implied that brand association might lead to reputation of private universities that compete with others. The competition among private universities had an impact on marketing performance for Thai private universities. For the perspective of brand loyalty, it was found that the stakeholder-based brand equity in curriculum and universities' facility should be considered to accommodate perspective students. A satisfaction level of lecturers and students may be relied on promptness of universities' facility. The results found were relevant to Pina et al. (2012) who studied research titled "consumer-based brand equity in banking industry". The purpose of this paper is to examine bank brand equity from consumer perspectives by comparing the consumer-based brand equity (CBBE) dimensions of local and global banks in Turkey. The paper determines if and how CBBE differs across three types of banks (state, private, and foreign). The results help foreign banks understand branding challenges/threats they may face from local banks in new markets. Such challenges might pertain to low levels of organizational associations and service quality perceived for foreign banks, as found in this study. The findings close the gap in the area of the brand equity theory that has not been adequately developed for the banking/financial industry. Another research study was conducted by Veloutsou et al. (2013). This research was titled taxonomy of measures for consumer-based brand equity". The purpose of this paper is to identify the components of consumer - based brand equity from the perspective of experts in brand management in the UK, Germany and Greece. The findings suggested four categories of measures which can be used to define brand equity. These are the consumers' understanding of brand characteristics; consumers' brand evaluation; consumers' affective response towards the brand; and consumers' behavior towards the 
brand. Specific dimensions are identified as indicators of each category.

\subsection{Recommendation}

This research study recommended that there should be other factors conducted to investigate the stakeholder-based brand equity such as brand sustainability and brand leadership, etc. This study focused on stakeholder-based brand equity, customer relationship management, marketing mix $7 \mathrm{~S}$, perceived service quality, marketing performance that fulfill the determined research hypotheses. The implications would be an application of the results used for public or private universities.

\section{REFERENCES}

[1] Ali M. Al-Khouri (2012), Customer Relationship Management: Proposed Framework from a Government perspective.

[2] Borden, N.H. (1984), The Concept of the Marketing Mix. Journal of Advertising Research, 2, pp. 7-12.

[3] Berry, L. (2002) Relationship marketing of services perspectives from 1983 and 2000. Journal of Relationship Marketing, 1(1) pp. 59-70.

[4] Chen, H.C. (2009). Marketing mix and branding: competitive hypermarket strategies. International journal of management and marketing research, 2(1), pp. 17-34.

[5] Cherukuri, J., \& Prodhuturi, V. V. K., (2012) . Antecedents and Consequences of Customer Satisfaction in Food \& Grocery Retailing: An Empirical Analysis. 39(3), pp. 101-140.

[6] Day, G.S., \& Van den Bulte, C. (2002). Superiority in customer relationship management: consequences for competitive advantage and performance. The Wharton School University of Pennsylvania, 9, pp. 1-48.

[7] Goldenberg, B.J. (2002). CRM Automation, Upper Saddle River, NJ: Prentice Hall.

[8] Hui-Chu Chen (2007), Customers' perceptions of the marketing mix and the effect on Taiwan hypermarkets' brand loyalty. Dissertation Presented in Partial Fulfillment of the Requirements for the Degree of Doctor of Philosophy. Lynn University.
[9] Hyung-su. K. (2008). A CRM performance measurement Framework: ITS development process and application.

[10] Kotler, P. (2003). Marketing Management (11th ed.). Prentice Hall International Editions.

[11] Kevin Lane Keller. (2009), "Building strong brands in a modern marketing communications environment." Journal of Marketing Communications Vol. 15, Nos. 2-3, April-July 2009, 139-155.

[12] Haejung K. (2012). The dimensionality of fashion-brand experience Aligning consumer-based brand equity approach.

[13] Jonathan I. (2008). A new higher education marketing mix: the 7Ps for MBA marketing. International Journal of Private Management, 22)4 (, pp.288-299.

[14] Jaehee, J. (2011). Consumer-based brand equity Comparisons among Americans and South Koreans in the USA and South Koreans in Korea.

[15] Rahmat M. (2013). Customer Trust as Relationship Mediation between Customer Satisfaction and Loyalty at Bank Rakyat Indonesia )BRI (Southeast Sulawesi.

[16] Mei-Lien L. (2011). Impact of Marketing Strategy Customer Perceived Value Customer Satisfaction Trust and Commitment on Customer Loyalty Establish Customer Satisfaction and Loyalty in Tehran's chain stored. Journal of Basic and Applied Scientific Research, 3(7), pp. 956-965.

[17] Parasuraman, A. (1985). A Conceptual Model of Service Quality and lts implications for Future Research. Journal of Marketing, 49, pp. 41-50.

[18] Parves, S (2011). Antecedents' consequences of service quality in a higher education context.

[19] Sirikada, Y. (2013). Antecedents and consequences of customer relationship management capability of hotels in Thailand.

[20] Sang Hee Park, M. S (2009). The Antecedents and Consequences of Brand Image: Based on Keller's Customer-Based Brand Equity.

[21] Vinta, K. (2013). Antecedents of customer satisfaction: a study of Indian public and private Sector banks. International Journal of Bank Management, 31(3), pp. 167-186.

[22] Wei-Tsong (2010). Factors influencing mobile services adoption: a brand-equity perspective.

[23] Yim, F. H., Anderson, R. E., \& Swaminathan, S. (2004). Customer relationship management: ITS dimensions and effect on customer outcomes. Journal of Personal Selling \& Sales Management, (4), pp. 265-280. 